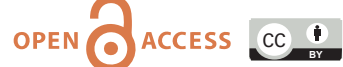

doi: 10.31729/jnma.5316

\title{
Prevalence of Hypertension in a Community
}

\author{
Pradeep Paudel, ${ }^{1}$ Samir Chalise, ${ }^{1}$ Dinesh Raj Neupane, ${ }^{1}$ Narayan Adhikari, ${ }^{1}$ Shishir Paudel, ${ }^{2}$ \\ Nim Bahadur Dangi' \\ 'Faculty of Health Sciences, School of Health and Allied Sciences, Pokhara University, Kaski, Nepal, ${ }^{2}$ Department of \\ Public Health, Manmohan Memorial Institute of Health Sciences, Kathmandu, Nepal.
}

\begin{abstract}
Introduction: Hypertension is one of the leading risk factors for global burden of disease and is of rising public health concerns in developing world including Nepal. However, few studies have focused on awareness, treatment, and control of hypertension among people living with this condition. In this scenario, this study aimed to find out the prevalence of hypertension and its awareness, treatment, and control among hypertensive patients residing in different parts of Kaski district, Nepal.
\end{abstract}

Methods: A descriptive cross-sectional study was performed among 977 family members of 290 households from August to December 2017. Ethical approval was taken from the Institutional Review Committee (reference number: 73/074/75) of the Pokhara University Research Center. Simple random sampling was done. Hypertension screening was performed through averaging three values obtained by standardized aneroid sphygmomanometer in three observations. Primary data was collected through self-administered questionnaires and face-to-face interviews based on participant's preferences. Collected data were analyzed using Statistical Package for the Social Sciences version 20. Point estimate at 95\% Confidence Interval was calculated along with frequency and proportion for binary data.

Results: Of total 997 family members screened, 294 (29.49\%) (26.66-32.32 at 95\% Confidence Interval) had hypertension whereas only 127 (43.2\%) were completely aware of their disease condition. 279 (94.9\%) were taking antihypertensive medication and 201 (68.4\%) had their blood pressure controlled.

Conclusions: We found that almost one-fourth of the adult population in the community suffered from hypertension but less than half of the hypertensive patients are aware of their conditions.

Keywords: awareness; control; cross-sectional study; hypertension; prevalence; treatment.

INTRODUCTION

Hypertension is a leading risk factor for the global burden of disease. ${ }^{1,2}$ In 2000 A.D. global estimate suggested approximately two-thirds of stroke and one-half of ischaemic heart disease were attributable to blood pressure. ${ }^{3}$ In 2005, this global burden was projected to rise from 0.9 billion in the year 2000 to 1.58 billion in $2025 .^{4}$

World Health Organization estimates low- and middle-income countries account for two-thirds of hypertensive patients and it's of rising public health concerns in developing world including Nepal.,5 In Nepal, a meta-analysis based on twenty-three studies reported the overall prevalence of hypertension at $28.4 \%(95 \% \mathrm{Cl}: 22.4-34.7 \%){ }^{6}$ With these rising concerns, it's important to understand the level of

Correspondence: Mr. Samir Chalise, Faculty of Health Sciences, School of Health and Allied Sciences, Pokhara University, Kaski, Nepal. Email: rajchalise40@gmail.com, Phone: +977. 9846649900 
awareness, treatment, and control of hypertension to develop evidence-based strategies. ${ }^{7}$

In this scenario, this study aimed to seek out the prevalence of hypertension along with awareness, treatment, and control of hypertension among hypertensive patients of Kaski district, Nepal.

\section{METHODS}

This was a descriptive cross-sectional study conducted among the residents of the Kaski District of Nepal from August to December 2017. The ethical approval was taken from the Institutional Review Committee (IRC) of Pokhara University Research Center (Ref No: 73/074/75). The people residing at Kaski districts at least for the past six months with an age above or equal to 18 years were included in the initial phase of the study for hypertension screening performed among 290 randomly selected households. However, residents suffering from severe physical and mental conditions limiting their ability to provide a proper response to the survey were excluded. The participants who were found to be hypertensive were eligible and thus involved in the study to understand their level of awareness, treatment and control of hypertension.

Sample size was calculated as,

$\mathrm{n}=\mathrm{Z}^{2} \times \mathrm{p} \times(1-\mathrm{p}) / \mathrm{e}^{2}$

$=(1.96)^{2} \times 0.22 \times 0.78 /(0.05)^{2}$

$=263.68$

$\approx 264$

where,

$\mathrm{n}=$ sample size

$\mathrm{Z}=1.96$ at $95 \%$ Confidence Interval (Cl)

$\mathrm{p}=$ prevalence of hypertension among community of central Nepal, 22.4\% ${ }^{8}$

$q=1-p$

$\mathrm{e}=$ margin of error, $5 \%$

Considering a $10 \%$ non-response rate the minimum sample size for this study was estimated at 290 hypertensive patients.

In this study, as there was no complete list of a hypertensive patient residing in the Kaski district so it was decided that the study will be carried out in two phases. In the first phase, the sample frame of the hypertensive patient was to be developed by screening hypertension among 290 randomly selected households representing each ward of the Metropolitan and four Rural-Municipalities of Kaski Districts. For this, the proportional to population size (PPS) method was adopted to estimate the required number of households to be selected from each ward of the study area to ensure representativeness based on the number of household data available from the 2011 census. $^{9}$ In the second phase, after preparing the sampling frame, simple random sampling was to be used for random selection of a minimum of 290 hypertensive patients from the sampling frame. However, during our screening 294 hypertensive patients were identified, which was near to our sample size so all 294 hypertensive patients were selected.

Permission from the formal District Health Office was acquired prior to initiation of the study whereas informed consent from all the participants was acquired before the data collection. The confidentiality of the participants was assured and maintained through the coding of the participants. The voluntary participation of the subject was encouraged as the participants were notified about their option to withdraw from the study at any time on their will.

The screening of family members to identify hypertensive patients was performed by taking three blood pressure readings by using a standardized aneroid sphygmomanometer and averaging the value of three readings. The primary data for this study was collected using a self-administered questionnaire following the WHO Stepwise Survey Manual Approach. ${ }^{10}$ Based on the participant's preference, the questionnaire was distributed as a self-administered questionnaire to those participants who were willing to answer the question on their own, whereas participants who requested assistance were helped through a face-to-face interview approach. The questionnaire was divided into four sections. The first section consisted of a question regarding a participant's socio-demographic profile whereas the second section focused on their awareness of hypertension, its prevention, and consequences. The third section consisted of information regarding participant's hypertension treatment, management, and control status covering medicines underuse, participant's lifestyle, and their hypertension control status through blood pressure reading. For this, three blood pressure readings were made on the left arm with participants in a seated position after at least 5 minutes of rest and one-minute interval by a well-trained health care professional with a standardized aneroid sphygmomanometer. The means of three readings was used for the analysis. The fourth section consisted of participant's anthropometric measurements where the height was measured without shoes using a fixed measurement tape and body weight without heavy clothing was measured using a weight measurement device.

In this study, hypertension was defined as systolic blood pressure (SBP) of $\geq 140 \mathrm{~mm} \mathrm{Hg}$ or diastolic blood pressure (DBP) of $\geq 90 \mathrm{~mm} \mathrm{Hg}$ or those who were receiving antihypertensive medication. ${ }^{11}$ Awareness was defined as a self-reported previous medical diagnosis of hypertension, its risk factors, and 
consequences. Treatment of hypertension was defined as the current use of antihypertensive medications intended to lower blood pressure. Body Mass Index was calculated as the weight in kilograms divided by square of height in meters $(\mathrm{kg} / \mathrm{m} 2)$ with a BMI cut-off point for overweight $(25-29.9 \mathrm{~kg} / \mathrm{m} 2)$ and obesity $(\geq 30$ $\mathrm{kg} / \mathrm{m} 2$ ) based on the categorization by $\mathrm{WHO} .^{12}$

The collected data was entered using Epidata software version 3.1 while the Statistical Package for the Social Sciences (SPSS) version 20 was used for the analysis. The collected data was analyzed using descriptive statistical methods such as frequency and percentage.

\section{RESULTS}

Out of a total 290 randomly selected households for the screening of hypertension, we screened 997 household members and found that 294 (29.49\%) (26.66-32.32 at $95 \% \mathrm{Cl}$ ) of the members had hypertension. Among 997 participants $534(53.5 \%)$ of the participants were females and the mean age $( \pm S D)$ of the participants was 47.98 years \pm 17.427 . Of the total participants, 793 $(79.5 \%)$ participants were aged between 18 and 64 years whereas 204 (20.5\%) of them were aged more than 64 years (Table 1).

Of the total 294 hypertensive participants, the mean age of the participants was $61.94 \pm 12.83$ years. 104 $(35.4 \%)$ of the participants were Brahmins followed by Dalit $62(21.1 \%)$ and other ethnicities. Similarly, 160 (55.4\%) of participants were illiterate and 214 (77.3\%) were engaged in a certain type of occupation.

\begin{tabular}{|c|c|}
\hline Characteristics & Frequency n (\%) \\
\hline \multicolumn{2}{|l|}{ Age group } \\
\hline Adult & $793(79.5)$ \\
\hline Elderly & $204(20.5)$ \\
\hline \multicolumn{2}{|l|}{ Gender } \\
\hline Male & $463(46.4)$ \\
\hline Female & $534(53.6)$ \\
\hline \multicolumn{2}{|l|}{ Marital status } \\
\hline Married & $753(75.5)$ \\
\hline Unmarried & $150(15)$ \\
\hline Widow & $94(9.5)$ \\
\hline \multicolumn{2}{|l|}{ Ethnicity } \\
\hline Brahmin & $413(41.4)$ \\
\hline Chhetri & $173(17.4)$ \\
\hline Dalit & $88(8.8)$ \\
\hline Gurung & $181(18.2)$ \\
\hline Others & $142(14.2)$ \\
\hline \multicolumn{2}{|l|}{ Educational status } \\
\hline Illiterate & $409(41)$ \\
\hline Primary education & $158(15.8)$ \\
\hline Secondary education & $240(24.1)$ \\
\hline Higher education & $190(19.1)$ \\
\hline \multicolumn{2}{|l|}{ Occupational status } \\
\hline Employed in the Service Sector & $260(26.1)$ \\
\hline Agriculture & $286(28.7)$ \\
\hline Unemployed & $308(30.9)$ \\
\hline Others & $143(14.3)$ \\
\hline
\end{tabular}

The rate of smoking and alcohol consumption was noted among 79 (26.9\%) and 61 (20.7\%) of the hypertensive patients respectively whereas 129 $(43.6 \%)$ were found to be overweight and $14(16 \%)$ had obesity (Table 2).

\begin{tabular}{|llll|}
\hline $\begin{array}{l}\text { Table 2. Distribution of demographic and health-related characteristics of hypertensive patients across } \\
\text { gender( } \mathrm{n}=294) .\end{array}$ & $\begin{array}{l}\text { All hypertensives } \\
\text { Male }(\mathrm{n}=117) \mathrm{n}(\%)\end{array}$ & Female $(\mathrm{n}=177) \mathrm{n}(\%)$ & Total $\mathrm{n}(\%)$ \\
\hline Variables & $76(65)$ & $92(52)$ & $168(57.1)$ \\
Age & $41(35)$ & $85(48)$ & $126(42.9)$ \\
Adult & & & $259(88.1)$ \\
Elderly & $115(98.3)$ & $144(81.4)$ & $2(0.7)$ \\
Marital status & $0(0)$ & $2(1.1)$ & $33(11.2)$ \\
Married & $2(1.7)$ & $31(17.5)$ & $104(35.4)$ \\
Unmarried & & $59(33.3)$ & $46(15.6)$ \\
Widow & $45(38.5)$ & $36(20.3)$ & $39(13.3)$ \\
Ethnicity & $10(8.5)$ & $21(11.9)$ & $62(21.1)$ \\
Brahmin & $18(15.4)$ & $35(19.8)$ & $43(14.6)$ \\
Chhetri & $27(23.1)$ & $26(14.7)$ & $60(20.4)$ \\
Gurung & $17(14.5)$ & $21(11.9)$ & $106(36.1)$ \\
Dalit & $39(33.3)$ & $69(39)$ & \\
Others & $37(31.6)$ & &
\end{tabular}




\begin{tabular}{|c|c|c|c|}
\hline \multirow[t]{2}{*}{ Variables } & \multicolumn{3}{|l|}{ All hypertensives } \\
\hline & Male $(n=117) n(\%)$ & Female $(\mathrm{n}=177) \mathrm{n}(\%)$ & Total n (\%) \\
\hline Unemployed & $18(15.4)$ & $62(35)$ & $80(27.2)$ \\
\hline Other & $23(19.1)$ & $25(14.1)$ & 48 (16.3) \\
\hline \multicolumn{4}{|l|}{ Education } \\
\hline Illiterate & $30(25.6)$ & $130(73.4)$ & $160(54.4)$ \\
\hline Primary education & $26(22.2)$ & $21(11.9)$ & $47(16)$ \\
\hline Secondary education & $41(35)$ & $19(10.7)$ & $60(20.4)$ \\
\hline Higher education & $20(17.1)$ & $7(4)$ & $27(9.2)$ \\
\hline \multicolumn{4}{|l|}{ Smoking } \\
\hline Smoker & $47(40.2)$ & $32(18.1)$ & $79(26.9)$ \\
\hline Non-smoker & $70(59.8)$ & 145 (81.9) & $215(73.1)$ \\
\hline \multicolumn{4}{|l|}{ Alcohol } \\
\hline Alcoholic & $43(36.8)$ & $18(10.2)$ & $61(20.7)$ \\
\hline Non-alcoholic & $74(63.2)$ & 158 (89.8) & $233(79.3)$ \\
\hline \multicolumn{4}{|l|}{ Exercise } \\
\hline Yes & $87(74.4)$ & $104(58.8)$ & $191(65)$ \\
\hline No & $30(25.6)$ & $73(41.2)$ & $103(35)$ \\
\hline \multicolumn{4}{|l|}{ BMI categories } \\
\hline Underweight $(<18.5 \mathrm{~kg} / \mathrm{m} 2)$ & $5(4.3)$ & $7(4)$ & $12(4.1)$ \\
\hline Normal-weight (18.5-24.9 kg/m2) & $44(37.6)$ & $64(35)$ & $106(36.1)$ \\
\hline Overweight (25.0-29.9 kg/m2) & $50(42.7)$ & $79(44.6)$ & $129(43.6)$ \\
\hline Obese $(\geq 30.0 \mathrm{~kg} / \mathrm{m} 2)$ & $18(15.4)$ & $29(16.4)$ & $47(16)$ \\
\hline \multicolumn{4}{|l|}{ Diabetes } \\
\hline Yes & $21(17.9)$ & $24(13.6)$ & $45(15.3)$ \\
\hline No & $96(82.1)$ & $153(86.4)$ & $249(84.7)$ \\
\hline
\end{tabular}

Out of 294 hypertensive patients, 127 (43.2\%) of the participants were found aware of their disease condition. Male participants were found to be more aware than female participants. Similarly, adult participants were more aware than elderly participants. Married participants and employed participants were found to be aware compared to their counterparts. Participants having higher education were found to be more aware than illiterate participants (Table 3).

\begin{tabular}{|c|c|c|c|}
\hline \multirow[t]{2}{*}{ Characteristics } & \multicolumn{3}{|c|}{ All hypertensives } \\
\hline & Aware n (\%) & Not Aware n (\%) & Total n (\%) \\
\hline Total & $127(43.2)$ & $167(56.8)$ & $294(100)$ \\
\hline \multicolumn{4}{|l|}{ Age } \\
\hline Adult & 77 (45.8) & $91(54.2)$ & $168(57.1)$ \\
\hline Elderly & $50(39.7)$ & $76(60.3)$ & $126(42.9)$ \\
\hline \multicolumn{4}{|l|}{ Sex } \\
\hline Male & $63(53.8)$ & $54(46.2)$ & $117(39.8)$ \\
\hline Female & $64(36.2)$ & $113(63.8)$ & $177(60.2)$ \\
\hline \multicolumn{4}{|l|}{ Marital Status } \\
\hline Married & $117(45.2)$ & $142(54.8)$ & $259(88.0)$ \\
\hline Unmarried & $1(50.0)$ & $1(50.0)$ & $2(0.01)$ \\
\hline Widow & $9(27.3)$ & $24(72.7)$ & $33(11.99)$ \\
\hline \multicolumn{4}{|l|}{ Ethnicity } \\
\hline Brahmin & $48(46.2)$ & $56(53.8)$ & $104(35.4)$ \\
\hline Chhetri & $17(37)$ & $29(63)$ & $46(15.6)$ \\
\hline Gurung & $15(38.5)$ & $24(61.5)$ & 39 (13.3) \\
\hline Dalit & $25(40.3)$ & $37(59.7)$ & $62(21.0)$ \\
\hline Others & $22(51.2)$ & $21(48.8)$ & $43(14.7)$ \\
\hline
\end{tabular}


Paudel et al. Prevalence of Hypertension in a Community

\begin{tabular}{|c|c|c|c|}
\hline \multirow[t]{2}{*}{ Characteristics } & \multicolumn{3}{|c|}{ All hypertensives } \\
\hline & Aware $\mathrm{n}(\%)$ & Not Aware n (\%) & Total n (\%) \\
\hline Illiterate & $45(28.1)$ & $115(71.9)$ & $160(54.4)$ \\
\hline Primary & $20(42.6)$ & $27(57.4)$ & $47(16.0)$ \\
\hline Secondary & $42(70)$ & $18(30)$ & $60(20.4)$ \\
\hline Higher Education & $20(74.1)$ & $7(25.9)$ & $27(9.2)$ \\
\hline \multicolumn{4}{|l|}{ Occupation } \\
\hline Employed in Service Sector & $44(73.3)$ & $16(26.7)$ & $60(20.4)$ \\
\hline Agriculture & $50(47.2)$ & $56(52.8)$ & $106(36.0)$ \\
\hline Unemployed & $14(17.5)$ & $66(82.5)$ & $80(27.2)$ \\
\hline Others & $19(39.6)$ & $29(60.4)$ & $48(16.4)$ \\
\hline
\end{tabular}

Among 294 hypertensive patients, 279 (94.9\%) were taking antihypertensive $(\mathrm{AH})$ medicines. It was found that Calcium Channel Blocker (CCB) was mostly prescribed medicine 109 (39.4\%), followed by Angiotensin Receptor Blocker (ARB) 84 (29.7\%), diuretics $30(10.8 \%)$, ACE Inhibitor 16 (5.7\%), and $\beta$-blocker $28(10.1 \%)$ whereas only $12(4.3 \%)$ of the participants were found to be taking other medicines. It was also noted that of these 279 hypertensive participants who were under treatment, the majority of then 181 (64.87\%) were taking monotherapy (only single drug) in their medication regimen whereas 98 $(35.13 \%)$ were using combined therapy (more than one drug) in their medication regimen. Similarly, 233 $(83.6 \%)$ of the participants were taking medicines based on doctor's prescription while 46 (16.4\%) took medicines directly from other healthcare professionals and pharmacists. (Figure 1).

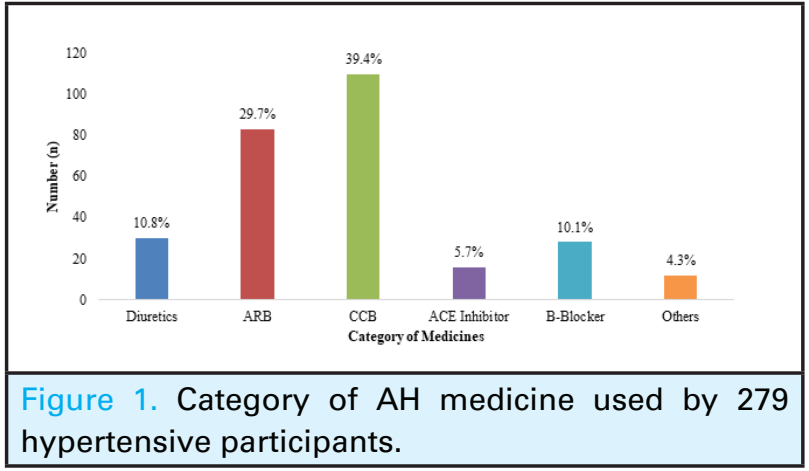

More than two-thirds (68.4\%) of hypertensive patients had their blood pressure under control after taking the medications (Table 4).

\begin{tabular}{l}
\hline \multicolumn{4}{|l|}{ Table 4. Factors influencing hypertension control } \\
among patients who were under medications $(\mathrm{n}=$ \\
279). \\
\begin{tabular}{llll|}
\hline Charac- & All hypertensive patients on treatment \\
teristics & Controlled & Uncontrolled & Total \\
& $\mathrm{n}(\%)$ & $\mathrm{n}(\%)$ & $\mathrm{n}(\%)$ \\
Total & $201(68.4)$ & $78(31.8)$ & $279(100)$
\end{tabular}
\end{tabular}

Table 4. Factors influencing hypertension control among patients who were under medications $(n=$ 279).

Charac- All hypertensive patients on treatment

teristics Controlled Uncontrolled Total

$\begin{array}{lll}\mathrm{n}(\%) & \mathrm{n}(\%) & \mathrm{n}(\%)\end{array}$

Age

Adult $\quad 116(73.4) \quad 42(26.6) \quad 158(53.7)$

Elderly $\quad 85(70.2) \quad 36(29.8) \quad 121(46.3)$

Gender

Male $\quad 83(74.1) \quad 29(25.9) \quad 112(40.1)$

\begin{tabular}{llll}
\hline Female & $118(70.7)$ & $49(29.3)$ & $167(59.9)$
\end{tabular}

Smoking

Smoker $\quad 45(61.6) \quad 28(38.4) \quad 73(26.16)$

Non-smoker $156(75.7) \quad 50(24.3) \quad 206$

(73.84)

Alcohol

Alcoholic $\quad 37(63.8) \quad 21(36.2) \quad 58(20.78)$

Non- $\quad 164(74.2) \quad 57(25.8) \quad 221$

alcoholic

(79.22)

Fat/oily food

Oily $\quad 23(67.6) \quad 11(32.4) \quad 34(12.18)$

Normal $136(69.7) \quad 59(30.3) \quad 195$

Less Oily $\quad 42(84.0) \quad 8(16.0) \quad 50(17.93)$

Exercise

$\begin{array}{llll}\text { Yes } & 144(77.0) & 43(23.0) & 187\end{array}$

$\begin{array}{llll} & & & \\ \text { No } & 57(62.0) & 35(38.0) & 92(32.94)\end{array}$

Awareness

Aware $\quad 97(80.08) \quad 23(19.2) \quad 120$

\begin{tabular}{llll} 
Not-aware & $104(65.4)$ & $5(34.6)$ & $\begin{array}{l}(43.02) \\
159 \\
(56.98)\end{array}$ \\
Diabetes & & & \\
Yes & $24(54.4)$ & $20(45.6)$ & $44(15.8)$ \\
No & $177(75.3)$ & $58(24.7)$ & $235(84.2)$ \\
\hline
\end{tabular}

\section{DISCUSSION}

In this community-based study, it was noted that 
the prevalence of hypertension lies at $29.49 \%$, with a higher proportion (79.5\%) of the patient belonging to the 18 and 64 years. A similar prevalence rate of hypertension at $28 \%$ was reported by another community-based study performed in Lekhnath city of Western Nepal, which is one of the major city of Kaski district. ${ }^{13}$ Likewise, a study based on 1073 participants of Dhulikhel Municipality of Nepal found that 298 participants have hypertension yielding a similar prevalence rate of 27.02 percent. ${ }^{7}$ Similarly, a slightly higher rate of prevalence of $38.9 \%$ was noted in the communities of the mid-western region of Nepal. ${ }^{14}$ Furthermore, the prevalence rate noted in our study falls under the estimated prevalence of hypertension at $28.4 \%(95 \% \mathrm{Cl}: 22.4-34.7)$ reported by a systematic review and meta-analysis of 2019 which was based on twenty-three studies performed in Nepal. ${ }^{6}$

We observed that only $43.2 \%$ of the hypertensive patients were aware of their condition. Almost the same finding was noted in a study performed in the suburban town of Dhulikhel Municipality of Nepal where $43.6 \%$ of all hypertensive patients were aware of their hypertension status. ${ }^{7}$ In the same way, a study based on the suburban area of Kathmandu valley reported the rate of awareness to be at $41.1 \% .{ }^{15}$ Similar observation was shared by a study conducted by Chow and colleagues among 142,042 participants of different communities of the different economies ranging from high-income countries to low-income countries where it was noted that only $26,877(46.5 \%)$ of the participant were aware of their hypertension status. ${ }^{16}$ However, in the context of high-income countries, it was noted that a large proportion of the hypertensive patients were aware of their condition. As overall awareness rate of hypertension among the patients was noted to be at $54.33 \%$ in China, $^{17} 74.4 \%$ in Brazil, $^{18} 83 \%$ in Canada, ${ }^{19}$ and $88 \%$ in the US. ${ }^{20}$ This difference in the awareness level of different countries suggested that awareness can depend on the social, educational, and economic status of the country.

Out of the total of 294 Hypertensive participants of our study 279 were using antihypertensive $(\mathrm{AH})$ medication yielding a treatment rate of $94.9 \%$. This rate of treatment is remarkably higher than similar studies conducted in different parts of Nepal as only $29 \%$ hypertensive participants of Surkhet district, $31 \%$ hypertensive participants of Lekhnath city, and $76.1 \%$ hypertensive participants of Dhulikhel Municipality were reported to be on hypertension medication. ${ }^{7,13,14}$ These differences might be due to a higher level of awareness and relatively easier and affordable access to treatment for our study population due to the presence of social health insurance schemes, easy transport access, and other difference in the level of services and facilities.
In this study, it was also noted that $68.4 \%$ of the hypertensive patients had their blood pressure under control. Similarly, the study from Dhulikhel Municipality had also noted that only $35.3 \%$ of those who were on treatment had blood pressure under control. However, the controlled blood pressure was observed to be very low at $8.3 \%$ of the patients of Surkhet districts and $6 \%$ of the hypertensive patients in sub-urban area of Kathmandu valley. ${ }^{14,15}$ The prime reason behind this result could be a higher percentage of hypertensive patients were on antihypertensive medication and mostly Calcium Channel Blocker (CCB). The use of different medicine and combination of medicines might have drastically influenced the rate of blood pressure control among these studies. Further studies are needed to understand the effects of different drugs and combinations of drugs for the control of blood pressure in this population subgroups. Further, improvement in health care services as compared to past, newly introduced health insurance schemes and the availability of low-cost drugs for hypertension management might also be the reason for these differences.

Although this study is one of the few studies to assess the awareness, treatment, and control status of hypertensive patients, this study has its limitations. The major limitation of this study is due to its descriptive nature over cross-sectional data which limits its scope as the causal inferences could not be drawn. Moreover, this study is based on one district of Nepal, this study is also not representative of the whole country due to the high ethnic, dietary, cultural, and geographical variation in the country.

\section{CONCLUSIONS}

Through this study, it was noted that almost one-fourth of the adult population suffers from hypertension but less than half of the hypertensive patients are aware of their conditions. A statistical relationship exists between awareness of hypertension and its control. Therefore, proper medical services and counseling should be provided by the doctor and other healthcare professionals to increase the level of awareness, treatment, and control of hypertension.

\section{ACKNOWLEDGEMENTS}

We would like to thank all the participants involved in the study.

\section{Conflict of Interest: None.}




\section{REFERENCES}

1. Bromfield S, Muntner P. High blood pressure: the leading global burden of disease risk factor and the need for worldwide prevention programs. Curr Hypertens Rep. 2013;15(3):134-6. [Full Text | DOI]

2. Lim SS, Vos T, Flaxman AD, Danaei G, Shibuya K, Adair-Rohani $\mathrm{H}$, et al. Acomparative risk assessment of burden of disease and injury attributable to 67 risk factors and risk factor clusters in 21 regions, 1990-2010: a systematic analysis for the Global Burden of Disease Study 2010. Lancet. 2012;380(9859):2224-60. [ PubMed | Full Text | DOI]

3. Lawes CM, Vander Hoorn S, Law MR, Elliott P, MacMahon S, Rodgers A. Blood pressure and the global burden of disease 2000. Part II: estimates of attributable burden. J Hypertens. 2006;24(3):423-30. [PubMed | Full Text | DOI]

4. Kearney PM, Whelton M, Reynolds K, Muntner P, Whelton PK, He J. Global burden of hypertension: analysis of worldwide data. Lancet. 2005;365(9455):217-23. [PubMed| Full Text $\mid \underline{\text { DOI] }}$

5. WHO. Hypertension. Key facts: World Health Organization [Internet]. Geneva: WHO;2019 [cited 2020 Oct 17]. Available from: https://www.who.int/news-room/fact-sheets/ detail/hypertension. [Full Text]

6. Huang Y, Guo P, Karmacharya BM, Seeruttun SR, Xu DR, Hao Y. Prevalence of hypertension and prehypertension in Nepal: a systematic review and meta-analysis. Glob Health Res Policy. 2019;4(1):11. [Full Text |DOI]

7. Karmacharya BM, Koju RP, LoGerfo JP, Chan KCG, Mokdad $\mathrm{AH}$, Shrestha A, et al. Awareness, treatment and control of hypertension in Nepal: findings from the Dhulikhel Heart Study. Heart Asia. 2017;9(1):1-8. [uued | Full Text | DOI]

8. Chataut J, Adhikari RK, Sinha NP. The prevalence of and risk factors for hypertension in adults living in central development region of Nepal. Kathmandu Univ Med J (KUMJ). 2011;9(33):13-8. [라bMed | Full Text | DOI]

9. National Population and Housing Census 2011 (National Report) []Internet]. Kathmandu: Central Bureau Statistics; 2012 [cited 2020 Oct 17]. Available from: https://unstats. un.org/unsd/demographic-social/census/documents/ Nepal-Census-2011-Vol1.pdf. [Full Text]

10. WHO. The WHO STEP wise approach to noncommunicable disease risk factor surveillance [Internet]. Geneva: WHO; 2017 [cited 2020 Oct 17]. Available from: https:/ / www.who. int/ncds/surveillance/steps/STEPS_Manual.pdf?ua=1. [Full Text]
11. Bergler-Klein J. What's new in the ESC 2018 guidelines for arterial hypertension : The ten most important messages. Wien Klin Wochenschr. 2019;131(7-8):180-5. [Full Text | DOI]

12. WHO. Obesity: preventing and managing the global epidemic. Report of a WHO consultation. World Health Organ Tech Rep Ser. 2000;894:i-xii,1-253. [ [PubMed| Full Text]

13. Neupane D, Shrestha A, Mishra SR, Bloch J, Christensen B, McLachlan CS, et al. Awareness, Prevalence, treatment, and control of hypertension in western Nepal. Am J Hypertens. 2017;30(9):907-13. [PubMed | Full Text | DOI]

14. Khanal MK, Dhungana RR, Bhandari P, Gurung Y, Paudel KN. Prevalence, associated factors, awareness, treatment, and control of hypertension: Findings from a cross sectional study conducted as a part of a community based intervention trial in Surkhet, Mid-western region of Nepal. PLoS One. 2017;12(10):e0185806. [Full Text | DOI]

15. Sharma D, Bkc M, Rajbhandari S, Raut R, Baidya SG, Kafle PM, et al. Study of prevalence, awareness, and control of hypertension in a suburban area of Kathmandu, Nepal. Indian Heart J. 2006;58(1):34-7. [PubMed]

16. Chow CK, Teo KK, Rangarajan S, Islam S, Gupta R, Avezum A, et al. Prevalence, awareness, treatment, and control of hypertension in rural and urban communities in high-, middle-, and low-income countries. JAMA. 2013;310(9):959-68. [ㄹued | Full Text | DOI]

17. Wang H, Zhang X, Zhang J, He Q, Hu R, Wang L, et al. Factors associated with prevalence, awareness, treatment and control of hypertension among adults in Southern China: A Community-Based, Cross-Sectional Survey. PLOS ONE. 2013;8(5):e62469. [라Med | Full Text | DOI]

18. Cipullo JP, Martin JF, Ciorlia LA, Godoy MR, Caçao JC, Loureiro AA, et al. Hypertension prevalence and risk factors in a Brazilian urban population. Arq Bras Cardiol. 2010;94(4):519-26. [PubMed | Full Text | DOI]

19. Wilkins K, Campbell NR, Joffres MR, McAlister FA, Nichol $\mathrm{M}$, Quach S, et al. Blood pressure in Canadian adults. Health Rep. 2010;21(1):37-46. [uued | Full Text]

20. Wolf-Maier K, Cooper RS, Kramer H, Banegas JR, Giampaoli $\mathrm{S}$, Joffres MR, et al. Hypertension treatment and control in five European Countries, Canada, and the United States. Hypertension.2004;43(1):10-7. [PubMed | Full Text | DOI]

(C) The Author(s) 2018

This work is licensed under a Creative Commons Attribution 4.0 International License. The images or other third party material in this article are included in the article's Creative Commons license, unless indicated otherwise in the credit line; if the material is not included under the Creative Commons license, users will need to obtain permission from the license holder to reproduce the material. To view a copy of this license, visit http://creativecommons.org/licenses/by/4.0/ 